\title{
Cultural Representations of Spain and Latin America in Spanish as a Foreign Language. A Critique
}

\section{Forteza Fernandez Rafael Filiberto ${ }^{1}$, Rubtsova Elena ${ }^{2}$}

${ }^{1}$ Ural Federal University, Ekaterinburg, Russia

${ }^{2}$ Ural Federal University, Ekaterinburg, Russia

Corresponding author: Forteza Fernandez Rafael Filiberto, rafaelforteza@gmail.com

Abstract. Though the surge in the study of Spanish as a foreign language (ELE - acronym in Spanish - español como lengua extranjera) is far from reaching that of English, research shows they share a common denominator: an interest to promote a prestige variant and a tendency to deny the barbarous colonial past regardless of the supposed language unity claimed in the Pan-Hispanic policy. This paper problematizes otherization processes in the discourse embedded in the passages and dialogues dealing with the Latin American cultural history. Based on primary sources, previous research, Grounded Theory on Critical Applied Linguistics, and an ideological conceptual square, a survey of twenty-one textbooks in the market today revealed that ELE otherizes the Latin American cultural history in the reading passages of cultural sections and language-focused exercises. This process is characterized by distortions of the past and present, generalizations, and utter lies to conceal what has happened since 1492 to pave the way for representations of Latin America as fertile ground for a new wave of exploitation in the 21st century. The paper concludes that by tackling these biases in textbooks, ELE teachers would assume an ethical position to help learners resist neoliberal ideology and policies. Conceived as a contribution to Critical Pedagogy, the paper suggests further research within ELE and comparisons with other colonial languages.

Keywords: otherization, cultural history, foreign language, critical pedagogy, neoliberalism, globalization, agency, affordances, decolonization

\section{Introduction}

Regardless of the ubiquitous expansion of English as the language of politics, commerce, and the internet among many others many other linguistic manifestations, other languages seem to have started to confirm Graddol's 
forecast for 2050 [Graddol, 2000] on the relative decline of English and the rise of Chinese, Hindi/Urdu, Spanish and Arabic. This 1997 observation that the global popularity of English was in no immediate danger but that its pre-eminent position would be challenged in some world regions and domains of use is already taking shape at least for Spanish in relation to the attractiveness of tourism and the potential of economic growth through investment and political partnership, especially from Russia and China, in Spanish-speaking Latin America as well their increasing contesting position to US hegemony.

In Russia, this interest in the Spanish language, however, is affected by the practice of teaching/learning Spanish as a foreign language [Enseñanza del español como lengua extranjera, heretofore ELE - acronym in Spanish] sole focus on the supposedly uncontaminated, refined Spanish spoken in the Iberian Peninsula as its "prestige" variant, neglecting the language as spoken in nineteen Latin American countries, despite the unity, fixedness, and cleanliness claims advanced by the Royal Spanish Academia [Real Academia de la Lengua Española] in the Pan-Hispanism policy. This ideologically biased stance of ELE reflects that for the Spanish Self, Latin America is still the subaltern Other. However, what is more worrisome is that ELE textbooks cannot be trusted in their representation of the Latin American cultural history, which is always portrayed through the colonial Self's perspective. As a result, and from the Other's post-colonial perspective, this paper problematizes the Self's representations about its relationship with the former colonies in ELE discourse.

\section{Literature Review}

In the global village, foreign language teaching is a vehicle for the transmission of not only language as such but also of ideological cultural patterns [Risager, 2018; Bori, 2018]. Bori asserts that as timely artifacts, textbooks "are not born in a vacuum [and] ... are influenced by the political, economic, and historical context where they were created" [p. 2] in the form of language ideologies modeled by "the cultural systems of ideas and feelings, norms and values, which inform the way people think about languages" [Weber and Horner, 2012, 16] and their cultures. Textbook discourse models unveil the assumptions the textbook writer (consciously or unconsciously) believes when writing [Gee, 2005]. That is, the linguistic patterns, discourse models, and cultural references represented in ELE textbooks have power as representation, action, and symbols [Kramsch, 2010] and as such, in the case of colonial 
languages necessarily reflect the contemporary cultural and linguistic vision of the former metropolis - the Self - and its former colonies - the Other.

From a cultural and linguistic viewpoints, the presence of the Spanish language in Latin America is the result of colonization, a cultural-linguistic process with deep political, economic, and social roots that though having happened more than 500 years ago still influences the present of, first, the indigenous inhabitants and second, the rest of the population. More than nine indigenous Latin American languages are spoken today, two of which Quechua and Guarani enjoy official status. This fact explains, first, that in Brazil, a former Portuguese colony as well as in the rest of Spanish-speaking Latin America, the indigenous population was not exterminated, nor was their culture during the Conquista (conquest) contrary to what happened in the Caribbean colonies (Cuba, Porto Rico, La Española (the Hispaniola, today's Haiti and the Dominican Republic), and Jamaica to mention only four. Monolingualism in these islands attests for the extermination of both the aboriginal population and their culture by the Spanish Conquistadores (conquerors) before they were lost to other European colonial powers. Finally, today's racial distribution in this part of the world attests for slavery, the infamous Spanish-Portuguese institution that modeled not only the economic but also the social and political relationships between colonizers and their slave population in Latin America to this day.

ELE textbooks as "cultural artefacts" [Gray, 2000] approach coloniality issues in ideo-politically biased ways. Risager [ibid] in her study of Caminando [2009] (On the Way) notes the Spanish (Us) vs the Latin American (Other) avoids everything that touches on the political conflicts of colonialism and thus the resulting post-colonial situation. Risager's work confirms Ros i Solé [2013] assertion on the misrepresentation of Latin American cultures in ELE coursebooks and in the choice of topics. This textbook-author and publisher approach disservices the students who are deprived of a systematic approach to the culture represented by most of the speakers of the language and whose "sole purpose is to devalue the corresponding cultures that engender speakers of the multiplicity of variations spoken in the world, which are scientifically neither superior nor inferior" [Macedo, 2019, 11].

This timely approach seems to reveal a systematic focus on culture previously revealed in an English language teaching textbook [Forteza, 2019; Forteza, Rubtsova \& Forteza, 2020 in print] that obscures the colonial and neocolonial past to advance neoliberal globalization where the former Western co- 
lonial power envisions the colonized as the ground where to obtain a renewed imperialist economic revitalization, and Spain is no alien to this socio-economic and political process. Spain ranks second in terms of choices where to buy property for Russian and CIS rich citizens, the fifth for Americans, and fourth in the world after the US, the UK, and Australia as well as the fourth likeliest receptor of investment in Europe and the world, according to the real state consultancy Frank Knight estimates in 2019. The stuck of foreign direct investment in Latin America in 2018 was, according to CEPAL, US \$ 2.3 trillion. Zanon [2017] reports that Spain is the leading European investor in Latin America, $25 \%$ more than the rest of the EU countries combined and second only to the US in banking and insurance, pension fund management, construction, electricity, water and gas, media and publishing, oil, telecommunications, and tourism [Chislett, 2003]. For instance, transnationals such as the communications conglomerate Telefonica and the Santander bank, which together with other " 76 companies representing $€ 300 \mathrm{~b}$... listed in the in the Madrid stock exchange ... generate almost half of their sales from Latin American investment." At the same time, investments in Startup Spanish businesses with interests in Africa, Latin America and Europe were above $€ 1.2$ b in 2018 [Torrego, 2018]. In other words, the opening of Latin American finances to world institutions such as the World Bank and the FMI and business integration with the rest of the world is paving the way for a second wave of exploitation. Neoliberal policies (first put into practice in Chile during Pinochet's times) are expressions of the deepened the socio-economic and political crisis in the subcontinent as well as the increasing pressure on those who resist such as Venezuela [see IMF Staff Report, 2016]. The connection between these economic realities and otherization processes is difficult to prove; however, it seems that the expansion of Spanish through ELE, like the expansion of English through ELT, though complex but clear is linked to the process of globalization and the neoliberal empire [Kumaravadivelu, 2006] and Spanish is also acting as one of the "beachhead[s] of globalization" [Block, 2014, 115] which is main reason behind multilingualism, multiculturalism and the like notions..

When connected with multilingualism, multilingual intercultural competence results in "monolingual thinking" in several languages, the French American scholar Claire Kramsch [2017] vehemently argues. The above assertion is grounded in foreign language teaching studies [Block, 2018; Block \& Gray, 2018] that demonstrate textbook content alignment with neoliberal 
ideology, where textbooks portrait and pack culture in inclusive and exclusive ways; for instance, the symbolism represented by French culture and language is preferable to that of other French-speaking countries [Coffey, 2013]. Bori [2018] shows that the teaching of European languages is "tailored according to the same principles promoted by the Council of Europe" in the promotion of an ideology in the form of consumerism which "reinforces the neoliberal discourse of globalization in persistent and subtle ways" [Kramsch \& Vinall, 2015, 25, cited by Bori, 2018, 60] and otherize the language and culture resulting from colonial times. This bias towards the Spanish peninsular voice and representation is ubiquitous in the way Latin American cultures are neglected in the [ELE] coursebook[s], which focus on Spanish modernity, rationality, and the world of work, while Latin America is associated with more exotic and backward practices [Ros i Solé, 2013, 175]. In other words, the present and future monopolization of Spanish by Spain in ELE obeys the rules of neoliberal globalization. To achieve that it must hide the colonial past [Rigaser, 2018] and constrain the geographical horizon in its language materials. In doing so, ELE otherizes purposefully.

\section{Methods}

This paper surveyed twenty-one ELE textbooks in the market today where the ideological conceptual square [Van Dijk, 1998; 2003] was the criterion used for the identification of cultural otherization processes and as a frame to identify the Self's and the Other's representations in the form of text and other semiotic communication means from a multimodal perspective [Kress and van Leeuwen, 1996; Van Leeuwen, 2008; Kress, 2010; Kalantzis and Cope, 2012]. The application of Grounded Theory as a scientific method for the construction of knowledge in the social sciences [Charmaz, 2014; Glaser \& Strauss, 2006; Hadley, 2017] allowed to synthesize a philosophical position derived from Critical Literacy and Postcolonial postulates to substantiate how ELE textbooks otherize Latin America cultural history. The use of DeepL software facilitated the accurate translations from Spanish into English of terms, propositions, and book titles.

\section{Results}

ELE textbooks sometimes feature speakers of other languages and variants of Spanish in the dialogs and monologs serving as language models. However, when Latin Americans are used the choice is extremely biased. 
First, the turn-taking given to the speaker is very short and limited to basic language functions such as greetings, introductions, or asking for information in ways that indexes them as outsiders to the Spanish peninsular context; second, the Latin Americans chosen are far from genuine representatives of the spoken language in their nations across the Atlantic. For instance, the highly successful ELE series Ven (Come) includes in New Ven 1 an additional CDR with thirty tracks under the title Voces de Latinoamérica (Latin American Voices). The tracks clearly illustrate a biased choice of speakers. The very inclusion of the CDR outside the language models in the textbook must be understood as otherization by indexicality; that is, the speakers are indexed as the Other(s) who speak the language differently from the Self in the coursebook. After listening to these tracks and confirming that in in this coursebook some Latin American countries are overrepresented while others are not even mentioned [Corti, 2019], Prof. Maria Aguilera Guisado asserted:

All of them evidence how the accent is marked to show how the Spanish spoken in this part of the world is inferior to that spoken in Spain. The language as spoken in Argentina is highlighted as a good model, whereas that spoken by Colombians, Venezuelans, and Chileans is portrayed as less elegant or more popular and less educated. There is no example of Mexican or Central American Spanish. The Cuban speaker is in no way a typical example. He seems to be a young man whose sociolect recognized by the aspiration of sounds, mispronunciations, and accent places him well outside the mainstream educated young Cuban and the population in general (personal information).

The representation of the Spanish colonial past in ELE is either silenced or mentioned in ways that do not fully comply with the historical truth seen from a Latin American perspective. In New Ven 1 (New Come 1) [2009], ¡A Bordo! 1 (On Board 1) [2013], Gente 1 (People 1) [2004], Mañana 1 (Tomorrow 1) [2003], and Sueña 1 (Dream 1) [2010], the language seems to have flown from the peninsula and landed in Latin America, and not the result of colonization. From a multimodal perspective, the maps of Latin America and Spain depicted in Ven 1 - units 1 and 2 - show how the geographical space in understood and communicated by the writers. The Latin American one is placed lower to the left and is surrounded by pre-Columbian objects of art with no captions, whereas the Spanish one is higher and more to the center of the page and surrounded by famous captioned 
Spanish landmarks. Though both maps capitalize the name of the countries in the first and of the regions in the second, the font size is slightly bigger and in the same color and shade for the Spanish. In the Latin American one, the name of the capitals is given in a much smaller font and a pale red. From a multimodal perspective, these visual and textual semiotic means of representing Spain and Latin America speak about the cultural superiority of the former colonial power, whereas its greatness is represented by the size and layout of the map on the page, the shade of colors used, different font sizes, and lack of symmetry in the colors. In other words, when put together and in sequence, the textbook seems to convey the message: Spanish resides in Spain not anywhere else.

This idea is not only put forward by Nuevo Ven 1 (New Come 1), Sueña 1 (Dream 1), for instance, also features the maps of Spain and Latin America (p. 21) to teach the name of places utilizing their geographical location. Due to their differences in size, a much larger perspective is drawn from the original map of Spain, but not of those Latin American or Caribbean countries that are small. This perspective - the size of Spain is $504,782 \mathrm{~km}^{2}$ - is significantly larger than any of the really large Latin American countries such as Mexico $\left(1,972,550 \mathrm{~km}^{2}\right)$ and Argentina $(2,780,400 \mathrm{~km} 2)$. This larger perspective, which is on what the students will focus, is almost the size of Brazil, one of the biggest countries in the world $\left(8.5 \mathrm{~m} \mathrm{~km}^{2}\right)$. In other words, the way ELE indexes Latin America as the insignificant Other.

When the textbook writers mention the colonial past, this is done in a way that always minimizes the bitterness it brought to Latin America. The resources used in this process are various. First, the colonization process is generalized to such an extent that Spain is freed from the barbarities it committed in America. For instance, Nuevo ELE Inicial (New Elementary ELE) states, "América Latina está formada por diversos países que fueron colonizados por varias naciones europeas" [2005, 66] (Latin America is made up of several countries that were colonized by several European nations). This statement is a lie. The English and the French were limited to explorations and the establishment of trade posts in the continent until the defeat of the Spanish Armada in 1588. By that time, Spain has already conquered all Latin America except Brazil which went to Portugal thanks to the Treaty of Tordesillas in June 1994. By the time the English, the French and the Dutch came to America - a fact that in no way excludes them from the barbarity and savagery of colonialism, the Spanish colonizers had explored Florida in 
1513, tried to settle in North Carolina in 1526, reached Kansas in 1539 and California in 1542. In other words, Spain was the pioneer of the colonization process and only gave way to other European powers, almost a century later, because it had tried to bite more than it could chew.

Similarly, Descubrir España y Latinoamérica (Discovering Spain and Latin America) [2008] reads, "En un pasado lejano este inmenso territorio se llamaba América española” [p. 7] (In the distant past, this immense territory was called Spanish America). The indefinite time scale phrase "distant past" implies that what happened long ago from 1492 to the end of the XIX century is so obscure that it is difficult to remember... and worth mentioning. However, the memory of colonization is still alive in Latin America and the consequences still felt in the architecture of its cities, the names of places, and artificial contemporary national borders, but most of all in the lives of the displaced aboriginal populations that have been suffering from the natural disruption of their habitus ever since.

Another resource used is to hide the horrors of the conquest is to distort the reality in such a way that it seems truthful. For instance, for Aula Internacional 1 [2004] and 2 [2007] (International Classroom), the Spanish arrived in America, as if they had known it existed. On the other hand, Rumbos Intermedio (Paths Intermediate) falsifies all the historical event. This course asserts, "Los primeros inmigrantes llegan de España en 1492 y rápidamente dominan la población nativa de cada área... a Latinoamérica llegan soldados (soldiers) que se mezclan con la población nativa, formando una nueva 'raza"' [p. 11] (The first immigrants arrived from Spain in 1492 and quickly dominated the native population of each area... soldiers arrived in Latin America and mixed with the native population, forming a new 'race').

The use of immigrants arrived is a euphemism to conceal what happened; quickly dominated is a blatant lie, and mixed is another. On their way to the Indies, the Spanish landed in the western hemisphere by accident and took possession of a previously unknown part of the world for the Europeans; they had to fight the native population that weakened by European diseases such as measles, typhus, cholera, and smallpox which brought the death to millions, the differences in weapons - iron against wood as well as the divide and conquer policy, opened the continent for Spain after the destruction of the Inca, Maya, and Aztec civilizations [Restall, 2003; Crosby, 2015]. The conquerors did not mix with the native populations but 
raped its women, pillaged, dispossessed, and destroyed [Wright, 2015; Anderson-Cordova, 2017] ancient civilizations.

Following this same line, the use of "Descubrimiento de América (The discovery of America) by Mañana 1 (Tomorrow 1) in "El día 12 de octubre es el Día de la Hispanidad; con ella se celebra en toda España el Descubrimiento de America" [p. 31] (The 12th of October is the Hispanic Day; with it the Discovery of America is celebrated all over Spain) may be all right for the Spanish but utterly wrong for Latin Americans. Sueña 4 (Dream 4) [2008] also mentions that many Latin American countries celebrate October 12 under many different names; it silences, however, that the date is mostly devoted to strengthening identity, cultural diversity, hybridity, and the meeting of two cultures rather than the so-called "discovery" [Todorov, 1982] for nobody can discover an inhabited geographical space. The term discovery - a European epistemic construction - also signals self-aggrandizement for it ignores the likelihood of pre-Columbian contact with other civilizations [Wiener, 1920; Von Wuthenau, 1975; Van Sertima, 1976].

In most ELE cultural representations, the history of the subcontinent seems to finish in the early 1500s and jumps to the late 1800s when Spain lost its last American colony, Cuba. This event is also manipulated as "Cuba consiguió la independencia de España" (Cuba achieved independence from Spain) in En Marcha 2 (On the Go 2) [2011, 2]; or "1898 fue un año importante para España porque significó el fin de una época: fue el año en que perdió la isla de Cuba frente a EE UU” (1898 was an important year for Spain because it meant the end of an era: it was the year in which the island of Cuba was lost to the United States) in En Marcha 4 (On the Go 4) [2014, 10]. Both propositions conceal that Spain was militarily defeated by the independentist forces when under a pretext the US intervened in the war, destroyed the Spanish war fleet in Santiago de Cuba and frustrated the Cuban hopes and became an American neo-colony.

This intervention was one of the first manifestations of US imperialism that inaugurated an era in the use of false flags in foreign policy and the Monroe Doctrine that declared Latin America as its backyard, and its right to intervene politically, economically, and militarily in this part of the world. From then on until 1994, the US government has "intervened successfully to change governments in Latin America a total of at least 41 times. That amounts to once every 28 months for an entire century" [Coatsworth, 2005, 
6] and continues trying to do now more in Venezuela, Cuba, and Nicaragua after its success in Bolivia 2019.

The second historical 'jump' covers more than seven decades. The cultural representations of Spain in ELE tend to conceal the horrors of Francoist Spain after the civil war as a result of which Spanish history and culture are free from more recent dark periods. These cultural history representations are shown as the transition and transformation from a dictatorial regime to a democracy with a constitutional monarchy, and elections. These help the country project, through ELE, the image of a modern European state, a member of the European community in 1986, and later the EU. Only Español en Vivo (Live Spanish) [2008], probably because it was a Russian made product, makes partial justice to the tumultuous years of the Spanish XX century, though it still clings to 'the discovery of America' myth.

In ELE's neo-colonial neoliberal view, Latin America is ready for the second wave of exploitation. Basic Spanish for Business and Finance [2011], for instance, situates learners in Mexico as a place of business trips, hotels, and handcraft import; Guatemala, as a good one for market penetration; Colombia, as a coffee producer; and Porto Rico, as a source of labor. Latin America is also portrayed as a place not only for tourism in Colloquial Spanish of Latin America 2 but also for investment. The view of Latin America as a profitable business area is also present in general purpose coursebooks such as Meta ELE Final 2 (Final Goal 2) [2014] in its approach to low cost future businesses as well as branding. In other words, Latin America is ready for neoliberal globalization.

\section{Conclusions}

Otherization processes in the discourse of ELE are incontrovertible facts. This discourse either silences differences in the developments of the language on both sides of the Atlantic, but more significantly neglects, conceals, and distorts Latin American cultural history by repeating ad nauseam myths and lies. Approaching culture issues in ELE from a critical perspective is a matter of ethics that entails significant effort in preparation and ways to deliver content by focusing more on discourse rather than only in the mere structures of the language, which are important but limit agency and affordances in language use. This move is, however, still difficult to understand and interiorize in professional contexts. 
Despite its limitations in scope and unavoidable adoption of an ideological position by the authors, this general survey of otherization processes in ELE is likely to contribute to the development of an interest in areas of research such as decolonization in language teaching, a step forward in contesting neoliberalism in education. Education in ELE looks like its counterpart in English and as such worth studying not only from a discourse perspective, but together with other multimodal semiotic means since the results suggest that the expansion of former European colonial languages need to conceal the past to control the present where L2 is part and parcel of the imposition of neoliberal policies accompanying globalization. This implies that research of cultural representations in the discourse of coursebook series in one language and those of other languages is likely to reveal incredible coincidences for the neoliberal project is only one despite its different lights, shades, and manifestations.

\section{Conflict of interests}

The authors declare that they have no conflict of interest.

\section{Acknowledgment(s)}

This research was financially supported by the Russian Foundation for Basic Research (Grant No. 17-29-09136\20 "Multilingualism in the Era of Post-literacy: Philosophical and Cultural Studies and Methodological and Pedagogical Development of a Multilingual Education Model").

\section{References:}

1. D. Graddol. The Future of English? Digital Edition created by the English Company (UK) Ltd. (2000). Retrieved from: https://www.teachingenglish.org.uk/ sites/teacheng/files/pub_learning-elt-future.pdf (Accessed 17 April 2019).

2. K. Risager. Representations of the World in Language Textbooks. Bristol: Multilingual Matters (2018). ISBN 978-1-78309-954-2

3. P. Bori. Language Textbooks in the Era of Neoliberalism. London: Routledge (2018). ISBN 9781138223196

4. J. Weber, K. Horner. Introducing Multilingualism. A social approach. London: Routledge (2012). ISBN 9781138244498

5. J. P. Gee. An Introduction to Discourse Analysis: Theory and Method, London: Routledge (2005). ISBN 0-415-21186-7 
6. C. Kramsch. The symbolic dimensions of the intercultural. Revised version of a plenary paper presented on 29 January 2010 at the Second International Conference on the Development and Assessment of Intercultural Competence at the University of Arizona, Tucson, Arizona. Language Teaching, 44(3) (2010), pp. 354-367, 10.1017/S0261444810000431

7. J. Gray. The ELT coursebook as cultural artifact: how teachers censor and adapt. ELT Journal Volume 54, Issue 3, July 2000, pp. 274-283. https://doi. org/10.1093/elt/54.3.274

8. Cristina Ros i Solé. "Spanish imagined: Political and subjective approaches to language textbook." In John Gray (Ed.) Critical perspectives on language teaching materials, (161-181). (2013). Basingstoke: Palgrave Macmillan. https://doi. org/10.1057/9781137384263_8

9. D. Macedo. Decolonizing Foreign Language Education. The Misteaching of English and Other Colonial Languages. NY: Routledge (2019). ISBN 9781138320697

10. R. Forteza Fernandez. Historical lies and distortions in ELT. A case study. Keynote speech at the International Conference on Multilingualism, Multiculturalism and Literacy. (2019, May). Ural Federal University, Ekateriburg, Russia

11. R. Forteza Fernandez, E. V. Rubtsova and S. Forteza Rojas. Content Edulcoration as ideology visualization in an English language coursebook. ПРАЕНMA. Journal of Visual Semiotics. 2020. Issue 4 (26). pp. 172-193. DOI: 10.23951/23127899-2020-4-172-193.

12. A. Zanon. Spain's 'Reconquista' of Latin America Comes with a Risk. (2017). https://corporateforeignpolicy.com/spains-reconquista-of-latin-america-comes-withrisk-f9942fa9adeb. (Accessed 20 May 2020).

13. W. Chislett. Spanish Direct Investment in Latin America. Madrid. Real Instituto Elcano (2003).

14. J. Torrego. Investments in Startups in Spain exceeds 1.2 billion for 2018. https://startupsreal.com/investment-in-startups-in-spain-exceeds-e1-2-billionfor-2018/(Accessed 22 June 2020).

15. IMF. Financial Integration in Latin America. Policy Paper (2016). https:// www.imf.org/external/np/pp/eng/2016/030416.pdf (Accessed 22 June 2020).

16. B. Kumaravadivelu. Dangerous Liaison: Globalization, Empire and TESOL. In J. Edge, (Re) Locating TESOL in an Age of Empire. Language and Globalization. London: Palgrave Macmillan (2006). ISBN 978-0-230-50223-9

17. D. Block. Social Class in Applied Linguistics. Oxon: Routledge (2014). 10.1017/S0267190514000221. (Accessed 2 May 2020). 
18. C. Kramsch. The Challenge of Education in the Era of Globalization. CARLA Presentation \& Open House, University of Minnesota: Minnesota. (2017, October). https://www.youtube.com/watch?v=ye7oj4ETuF4. (Accessed 12 May 2020).

19. D. Block. Political economy in sociolinguistics: Neoliberalism, inequality and social class. London: Bloomsbury (2018). ISBN-13: 978-1474281447

20. D. Block, J. Gray. "French language textbooks as ideologically imbued cultural artefacts: Political economy, neoliberalism and (self)branding." In Simon Coffey and Ursula Wingate (Eds.) New directions for language learning in the 21st century (pp. 115-131). London: Routledge (2018).

21. S. Coffey. Communicating Constructions of Frenchness through Language Coursebooks: A Comparison. In John Gray (Ed.) Critical perspectives on language teaching materials, (137-160). Basingstoke: Palgrave Macmillan (2013). https://doi. org/10.1057/9781137384263_8

22. T. Van Dijk. Ideology. A Multidisciplinary Approach. London: SAGE (1998). ISBN-13: 978-0761956556

23. T. Van Dijk. Ideology and discourse. A Multidisciplinary Introduction (2003). http://www.discourses.org/UnpublishedArticles/Ideology\%20and\%20discourse.pdf (Accessed 5 May 2020).

24. G. Kress, T. Van Leeuwen. Reading Images. The Grammar of Visual Design. NY: Routledge (1996). ISBN10: 0-415-31914-5 (hbk)

25. T. Van Leeuwen. Discourse and Practice. New Tools for Critical Discourse Analysis. Oxford: OUP (2008). ISBN-13: 978-0195323313

26. G. Kress. Multimodality. A Social Semiotic Approach to Contemporary Communication. London: Routledge (2010). ISBN-13: 978-0415320610

27. M. Kalantzis, B. Cope. New Learning. Elements of a Science of Education, 2nd Ed. Cambridge: CUP (2012). ISBN-13: 978-1107644281

28. K. Charmaz. Constructing Grounded Theory, 2nd Ed. Los Angeles: SAGE (2014). ISBN-13: 978-0857029140

29. B. Glaser, A. Strauss. The Discovery of Grounded Theory. Strategies for Qualitative Research. London: AldineTransaction (2006). ISBN- 0202302601.

30. G. Hadley. Grounded Theory in Applied Linguistics Research. London: Routledge (2017). ISBN-13: 978-1138795105

31. A. Corti. The construction of culture in Spanish as a foreign language (SSL) [La construcción de la cultura en el español como lengua extranjera (ELE)]. Münster: Waxman (2019). ISBN 978-3-8309-4009-8

32. F. Marín Castro, R. Morales, S. Rosa. Nuevo Ven 1 [New Come 1], 2nd Ed. Madrid: Edelsa Grupo DIASCALIA (2009). 
33. O. Balboa Sánchez, R. Gracía Prieto, M. Pujol Vila. A Bordo 1 [On Board 1]. Método de Español para Extranjeros. ELI-SGEL (2013).

34. E. Martín Peris, N. Sans Baulenas. Gente 1 [People 1]. Curso de Español Basado en Tareas. Barcelona: Difusión (2004).

35. I Barbera, P. Zaragueta. Mañana 1 [Tomorrow 1]. Libro del alumno. Anaya ELE (2003).

36. M. Álvarez Martínez, A. Blanco Canales, M. Gómez Sacristán, N. Perez de la Cruz. Sueña 1 [Dream 1], 13th Ed. Anaya ELE (2010).

37. V. Borobio Carrera. Nuevo ELE Inicial [New ELE Beginners]. Instituto Cervantes. SM-ELE (2005).

38. A. Ribas Casasayas. Descubrir España y Latinoamérica [Discover Spain and Latín America]. Cideb (2008).

39. J. Corpas, E. García, A. Garmendia, \& C. Soriano. Aula Internacional 1 [International Classroom 1]. Difusión ELE (2004).

40. J. Corpas, A. Garmendia, C. Soriano, \& N. Sánchez. Aula Internacional 2 [International Classroom 2]. Difusión (EMDL) (2007).

41. M. Restall. Seven Myths of the Spanish Conquest. Oxford: OUP (2003). ISBN-13: 978-0195176117

42. A. Crosby. Ecological Imperialism. The Biological Expansion of Europe, 900-1900, 2nd Ed. Cambridge: CUP (2015). ISBN-13: 978-0521546188

43. R. Wright. Stolen Continents: Conquest and Resistance in the Americas. Modern Classics Penguin (2015). ISBN: 9780143192084

44. K. F. Anderson-Córdova. Surviving Spanish Conquest. Indian Fight, Flight, and Cultural Transformations in Hispaniola and Puerto Rico. Alabama: The University of Alabama Press (2017). ISBN-13: 978-0817319465

45. Blanco, A. Canales, M. Fernández López, M. Torréns Álvarez. Sueña 4 [Dream 4], 8th Ed. Anaya ELE (2008).

46. S. Todorov. La Conquista de América. El Problema del Otro [The Conquest of America. The Other's Problem] (1982). https://www.academia.edu/31593585/ LA_CONQUISTA_DE_AM\%C3\%89RICA_por_Tzvetan_Todorov (Accessed 15 April 2020).

47. L. Wiener. Africa and the Discovery of America. Philadelphia: Innes \& Sons (1920).

48. A. Von Wuthenau. Unexpected Faces in Ancient America (1500 B. C. A. D.1500): The Historical Testimony of Pre-Columbian Artists. New York: Crown Publishers, Inc. (1975). 
49. I. Van Sertima. They Came Before Columbus. New York: Random House (1976).

50. F. Castro Viúdez, I. Rodero Diéz \& C. Sardinero Franco. En Marcha 2 [On the Go 2]. SGEL ELE (2011).

51. F. Castro Viúdez, I. Rodero Diéz, \& C. Sardinero Franco. En Marcha 4 [On the Go 4]. SGEL ELE (2014).

52. J. Coatsworth. United States Interventions. What for? ReVista Harvard Review of Latin America. Spring/Summer 2005, pp. 6-9. https://revista.drclas.harvard. edu/book/united-states-interventions (Accessed 9 April 2020).

53. G. Nuzhdin, C. Marin Estremera \& P. M. Lora-Tamayo. Español en Vivo [Live Spanish]. Moscú: Airis Press (2008).

54. A. C. Jarvis, L. Lebredo. Basic Spanish for Business and Finance, 2nd Ed. Boston: Heinle, Cengage Learning (2011).

55. J. Rodríguez Martin, L. Pérez de la Fuente. Meta Final 2 [Final Goal 2]. Edelsa (2014). 